\title{
Earnings Management Of Mergers And Acquisitions Of Target Candidates And Deal Withdrawn
}

\author{
Joo-hyun Lim, Baewha Women's University, South Korea \\ Jin-ho Chang, Yonsei University, South Korea
}

\begin{abstract}
In this paper, we investigate the tendencies of target candidate companies to manage earnings, which affects financial reporting quality, in order to increase transaction value, and the withdrawal of deals as a result of low financial reporting quality in M\&A in a sample of 316 mergers and acquisitions in South Korea between 2002 and 2011. Using the accruals quality measure developed by Dechow and Dichev (2002) as a proxy for financial reporting quality, we find the following. First, the financial reporting quality of target candidate firms is lower than that of non-target candidate firms because target candidate firms engage in earnings management prior to M\&A. Second, low-quality financial reporting of target firms is positively related to the likelihood of deal withdrawal as a result of poor financial reporting quality.
\end{abstract}

Keywords: M\&A; Target; Financial Reporting Quality; Deal Withdrawal

\section{INTRODUCTION}

examine earnings management in target candidate firms before mergers and acquisitions
(hereafter M\&A) and the likelihood that the proposed M\&A will be withdrawn as a result of poor
financial reporting quality in South Korea.

Whereas firms can make ongoing benefits (i.e., a lower financing cost) from submitting higher-quality accounting information, in the case of M\&A, target firms get better when their financial reports are low. As described in McNichols and Stubben (2012), if accounting quality in target firms is poor, the value of their assets is uncertain and difficult to estimate. Therefore, there is greater variation in target firm value across potential bidders, and selling shareholders benefit to a greater extent because the expected winning bid will be higher. Thus, if target firms manage accounting information to influence over bidding price, they must have a potentially higher one-time profit from M\&A with lower-quality accounting reporting. However, accounting quality plays an important role in the due diligence of an M\&A. As such, excessively low-quality accounting causes deal withdrawal and failure to sell target firms.

The results of this study are as follows. First, we find that the financial reporting quality of target candidate firms is lower than that of non-target candidate firms. Target firms have a tendency toward lower accounting quality in order to increase transaction value in M\&A. This result is similar to those of other studies that discuss earnings management in firms with initial public offerings and seasoned equity offerings, which are also trying to increase transaction value (Teoh, Welch, \& Wong, 1998; Fields, Lys, \& Vincent, 2001). Second, we find that low financial reporting quality of target firms is positively related to the likelihood of deal withdrawn. Based on the first and second results, we argue that when target firms manage earnings excessively, which affects accounting quality negatively, in order to increase transaction value in M\&A, deal withdrawal is more likely to occur. Deal completion is the minimum hurdle necessary to realize profit for target firms to sell in their own interest. As such, firms desiring to be targeted should maintain at least a market average level of accounting quality.

Section 2 presents the hypotheses and the basis for our predictions, and Section 3 presents the details of the sample and research design. Section 4 describes the results, and Section 5 concludes. 


\section{HYPOTHESES AND BASIS FOR PREDICTION}

\subsection{Target Candidates and Financial Reporting Quality of Target Firms}

The use of aggressive accrual accounting policies to inflate current earnings prior to major corporate events has been of particular interest to both accounting and finance academics. Several studies to date have suggested that acquirers use discretionary accruals to inflate earnings prior to the merger announcement. Erickson and Wang (1999) suggest that managers engage in earnings management prior to stock-based acquisitions due to their incentives to increase their firm's stock price prior to the acquisition for the US M\&A market. In addition, Botsari and Meeks (2008) document that acquirers make income-increasing accrual manipulation in the period preceding the bid announcement to raise the market value of their stock for the UK takeover market. Louis (2004) also finds that stock-for-stock acquirers manage earnings in the quarter prior to the announcement, and that future stock price declines of acquiring firms are in part due to a reversal of the effects of pre-merge earnings management. Existing research has identified earnings management around stock-swap M\&A from the point of view of the acquirer.

Similar to acquiring firms, target firms may also have an incentive to increase per acquisition earnings. Erickson and Wang (1999) observe that "it seems reasonable to believe that both the acquirer and the target would anticipate that the other would manage pre-merger earnings, and that each would adjust the transaction price". However, in the case of earnings management by target firms, empirical evidence is limited. Erickson and Wang (1999) show that unexpected accruals for target firms were positive before M\&A, but not statistically significant compared to acquirers from U.S. firm 1985-1990. North and O'Connel (2002) report that target firms managers reported increased earnings preceding and following M\&A attempt. Target firms inflate current earnings prior to the transaction in the case of a hostile merger (Easterwood, 1998; Guan, Wright, Sun, 2004). They suggest that managers convince target shareholders to reject the offer in order to maintain their own positions within firms. Managers of target firms deflate current earnings prior to mergers in the case of a friendly merger in order to maintain their management positions and to report better results in the post-merger period (Ben-Amar \& MisisonerPiera, 2008).

We focus on target firms' incentive to manage earnings to increase transaction value and the effect of this behavior on financial reporting quality. Whereas firms can achieve ongoing benefit from reporting higher-quality accounting information (i.e., a lower cost of capital), in the specific case of acquisitions, target firms fare worse when their financial reports are of higher quality. As described in McNichols and Stubben (2012), if accounting quality in target firms is poor, the value of the asset is uncertain and difficult to estimate. Therefore, there is greater variation in target firm values across potential bidders and the selling shareholders benefit to a greater extent from winning bids because the expected winning bid will be higher. Thus, target firms have incentives to manage earnings, which affects financial reporting quality negatively, in order to increase transaction value in M\&A. This leads to the following hypothesis:

H1: The financial reporting quality of target candidate firms is lower than that of non-target candidate firms.

\subsection{Financial Reporting Quality of Target Firms and Deal Withdrawal}

Acquirers gather and evaluate public information about the target firm to begin assessing whether to pursue a potential acquisition during preliminary due diligence. This includes reviewing the company's financial reports and other public information included in business report files. Public information can be gathered from analyst reports, articles in the business press, materials on corporate websites, and product brochures. The target firm first draws up a list of potential bidders. If prospective buyers sign a confidentiality agreement, they are then invited to participate in the next step of the process, the due diligence review, which involves more intensive dissemination of information, including presentations about internal financial statements, management reports and projections, copies of major contracts, discussions with senior management, plant and site visits, and review of financial, legal, and other documents that are assembled by the target firm and its advisors in the data room. It is important to note that although the information given to prospective bidders at this stage is extensive, it is chosen by the target firm and may therefore be incomplete. 
After the winning bid is chosen, the winning bidder and target firm then execute and sign an acquisition agreement, after which the acquirer must conduct traditional due diligence. The acquisition agreement is a binding contractual obligation between the acquirer and target necessary to complete the transaction, but it does not guarantee completion. The acquisition agreement may include an investigation covenant, representations and warranties, and conditions to closing. The investigation covenant requires target firms to continue to provide acquirers with access to private information. Representations and warranties included in acquisition agreements are designed to certify the accuracy of the information which the target firm provides to the acquirer throughout the entire due diligence process. Representations also and ensure that there has been no material adverse change in the target's business as of the time of closing. Market-wide events (e.g., changes in industry conditions, new regulations) or target firmspecific events (e.g., litigation, earnings restatements, loss of key customers, sharp declines in stock price) represent material adverse changes that can ultimately result in deal termination or renegotiation (Denis \& Macias, 2011).

Financial reporting quality plays a leading part in the due diligence of a deal because the review of financial statements is considered the most important section of due diligence. In this process, acquirers obtain more current and increasingly precise information, which is useful for valuing the assets acquired and liabilities assumed. Acquirers engage in activities such as reviewing the accounts receivable for collectability, counting inventories, intangible assets and searching for unreported liabilities and information. Relevant information is input into valuation models to value target firms. High-quality financial reporting reduces the costs of due diligence and renegotiation because it minimizes disagreement between bidders and target firms about target firm value before due diligence. Bates and Lemmon (2003) and Marquardt and Zur (2012) report that some of announced deals are withdrawn prior to completion. These results of prior studies support that part of acquisition agreement is cancelled during due diligence period.

Low-quality financial reporting increases the cost of the due diligence process and renegotiation costs and increases the possibility of deal withdrawal because there is more disagreement between the acquirer and the target firm about the target's value before the due diligence process begins. This leads to the following hypothesis:

H2: The lower the financial reporting quality of the target firm, the higher the likelihood of deal withdrawal.

\section{SAMPLE AND RESEARCH DESIGN}

\subsection{Sample Description}

The M\&A sample is available from the S\&P Capital IQ database. Annual financial statement of the acquirer company and target firm is extracted from the KIS-VALUE, or KISLINE databases. The acquiring firms are Korean firms publicly traded on the Korea Stock Exchange and target is also a Korean firm. The sample includes all the acquisitions in which more than $20 \%$ of the target company was acquired. In this study, M\&A is defined as acquiring significant shares of target firms. In the process of sample selection, some data was lost due to incomplete financial information for target firms. In order to measure accounting quality in accordance with the hypotheses, financial data for at least four consecutive years is needed. Since many of the targets were young companies, data for four consecutive years was unavailable. In total, 258 completed acquisitions and 58 cancelled acquisitions are identifiable between January 1, 2002 and December 31, 2011.

\subsection{Definition of Financial Reporting Quality}

Higher-quality earnings reports provide more information about the features of a firm's financial performance that are relevant to a specific decision made by a specific decision-maker (Dechow \& Schrand 2010). The Statement of Financial Accounting Concepts No.1 (SFACNo.1) states that financial reporting should provide information that is useful to present and potential investors and creditors and other users in making rational investment, credit, and similar decisions. Information about earnings based on accrual accounting generally provides a better indication of an enterprise's present and continuing ability to generate favorable cash flows than information limited to the financial effects of cash receipts and payments. Therefore, we conceptually define higher-quality financial reporting as that which provides more information about a firm's future cash flows that are relevant to M\&A decision-making by the management of the acquiring firm and the target firm. 


\subsection{Measurement of Financial Reporting Quality}

We use a measure of accruals quality as a proxy for financial reporting quality according to the method of Dechow and Dichev (2002) (hereafter DD) which are also used in Yoo, Lim \& Chang (2013). According to DD, the measurement is founded on the concept that accruals are adjusted earnings that map into cash flows. Therefore, adjusted earnings supply a great measure of firm performance. In this model, accruals quality is measured by the extent to which working capital accruals map into operating cash flow realization as described in equation (1). I multiply absolute residuals from equation (1) by minus one so that this variable increases as accruals quality increases, as described in equation (2). All variables are scaled by total assets.

$$
\Delta W C_{I, T}=\beta_{0}+\beta_{1} C F_{i, t-1}+\beta_{2} C F_{i, t}+\beta_{3} C F_{i, t-1}+\varepsilon_{i, t}
$$

where,

$\Delta \mathrm{WC}=(\Delta \mathrm{CA}-\Delta \mathrm{Cash})-(\Delta \mathrm{CL}-\Delta \mathrm{STD})$

$\Delta \mathrm{CA}=$ change in current assets

$\Delta$ Cash $=$ change in cash and cash equivalents

$\Delta \mathrm{CL}=$ change in current liabilities

$\Delta \mathrm{STD}=$ change in short-term debt

$\mathrm{CF}=$ cash from operations from the statement of cash flows

$A Q_{i, t}=(-1) *\left|\varepsilon_{i, t}\right|$

Where,

$\mathrm{AQ}=$ accruals quality

$\varepsilon=$ residual from Equation (1)

\subsection{Empirical Models}

We examine whether the financial reporting quality of the target candidate firms is lower than that of non-target candidate firms in testing of hypothesis 1 with the following model.

$$
\begin{aligned}
& \text { AQtarget }_{i, t}=\beta_{1}+\beta_{2} \text { Targetcanidate }_{i, t-1}+\beta_{3} \text { Size_target }_{i, t-1}+\beta_{4} \text { Leverage_target }_{i, t-1}+ \\
& \beta_{5} \text { Growth_target }_{i, t-1}+\beta_{6} \text { CFO_target }_{i, t-1}+\text { IndustryDummy }_{\text {Ind }}+\text { Yeardummy }+\varepsilon_{i, t}
\end{aligned}
$$

The dependent variable, accruals quality of target (AQtarget), is used as a proxy for financial reporting quality as discussed in Section 3.2. The independent variable, target candidate, is a dummy variable coded as 1 if a firm is a target candidate, and 0 otherwise. Target candidate firms include both firms that were actually sold and firms that planned to be sold, but for which the offer was withdrawn. We include four control variables for firm characteristics, industry, and year effect. For control firms(which are not target candidates), we use a propensity score matching model and select three times the number of firms. Control firms are matched for specific characteristics of the target candidate firms, such as size, leverage, and growth rate.

We examine whether the financial reporting quality of target firms is negatively associated with deal withdrawal in testing of hypothesis 2 with the following model.

$$
\begin{aligned}
& \text { Dealcompleation }_{i, t}=\beta_{1}+\beta_{2} \text { AQtarget }_{i, t-1}+\beta_{3} \text { Size }_{i, t-1}+\beta_{4} \text { Leverage }_{i, t-1}+\beta_{5} \text { Tobin }_{i, t-1} \\
& +\beta_{6} \text { Cash }_{i, t}+\beta_{7} \text { Relativevalue }_{i, t}+\beta_{8} \text { Size_target }_{i, t-1}+\beta_{9} \text { Leverage_target }_{i, t-1}+ \\
& \beta_{10} \text { After_crisis }_{i, t}+\text { IndustryDummy }_{-}+\text {YearDummy } \\
& +\varepsilon_{i, t}
\end{aligned}
$$

The dependent variable, deal completion, is a dummy variable coded as 1 if the deal is completed, and 0 otherwise. The independent variable, accruals quality of target(AQtarget), is used as a proxy for financial reporting quality of target. Acquirer characteristics, including firm size, leverage, and Tobin's q are controlled. Deal characteristics, including method of payment (Cash) and relative deal value (Relativevalue), are controlled. To control target traits, 
we include target firm size (Size_Target) and leverage (Leverage_target). Finally, we utilize control variables representing market conditions before and after the financial crisis (After_crisis) of 2008, industry effects, and the year effect.

\section{RESULTS}

\subsection{Descriptive Statistics and Correlations}

Panel A and Panel B of Table 1 lists the descriptive statistics resulting from hypothesis testing 1 and 2 respectively. As we select three times of firms as a control group (non-target candidate firms), the mean of Targetcandidate in Panel A is 0.25 . The mean of Dealcompletion in Panel B is 0.8165 and it means $81.65 \%$ of M\&A deals are finally completed and $28.35 \%$ of deals are withdrawn.

\subsection{Multivariate Analysis}

Table 2 reveals the results of the logistic regression analysis based on the estimation in Equation (3) related to hypothesis 1 , which compares the financial reporting quality of target candidate firms with that of non-target candidate firms. As predicted in $\mathrm{H} 1$, the coefficients of Targetcandidate are negative and significant at the 5\% level. This result suggests that target firms have a tendency to manage earnings, which affects financial reporting quality, in order to increase transaction value. If target firms influence over accounting quality, target firms must have a potentially higher one-time profit related with having lower-quality accounting information.

Table 1. Summary statistics

\begin{tabular}{|c|c|c|c|c|c|c|}
\hline \multicolumn{7}{|c|}{ Panel A. Target candidate and control firms } \\
\hline Variable & $\mathbf{N}$ & Mean & Median & StdDev & Min & Max \\
\hline AQtarget & 1264 & -0.1047 & -0.0700 & 0.1136 & -0.7081 & 0.0000 \\
\hline Targetcandidate & 1264 & 0.2500 & 0.0000 & 0.4332 & 0.0000 & 1.0000 \\
\hline Size_target & 1264 & 24.5681 & 24.1801 & 1.5161 & 22.0023 & 29.2391 \\
\hline Leverage_target & 1264 & 0.5556 & 0.5636 & 0.2599 & 0.0461 & 0.9952 \\
\hline Growth_target & 1264 & 0.1330 & 0.0660 & 0.4396 & -1.2158 & 2.2123 \\
\hline \multicolumn{7}{|c|}{ Panel B. Completed deals and Cancelled deals } \\
\hline Variable & $\mathbf{N}$ & Mean & Median & StdDev & Min & Max \\
\hline Dealcompletion & 316 & 0.8165 & 1.0000 & 0.3877 & 0.0000 & 1.0000 \\
\hline AQtarget & 316 & -0.1180 & -0.0798 & 0.1262 & -0.7081 & 0.0000 \\
\hline Size & 316 & 26.5655 & 26.1412 & 2.0565 & 22.9691 & 31.5062 \\
\hline Leverage & 316 & 0.4717 & 0.4917 & 0.1999 & 0.0692 & 0.9148 \\
\hline TobinQ & 316 & 1.2668 & 1.0749 & 0.7279 & 0.4031 & 4.7773 \\
\hline Cash & 316 & 0.7722 & 1.0000 & 0.4201 & 0.0000 & 1.0000 \\
\hline Rv & 316 & 0.1666 & 0.0680 & 0.2118 & 0.0001 & 0.9353 \\
\hline
\end{tabular}

For variable definitions, see appendix I.

Table 2. Financial reporting quality of target firms and acquisition target candidates

\begin{tabular}{|c|c|c|}
\hline \multicolumn{3}{|c|}{ 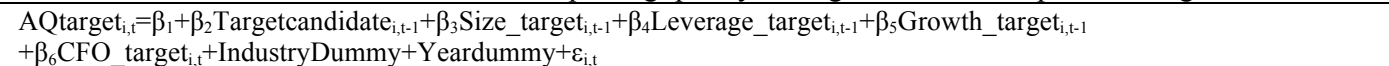 } \\
\hline Variable & Coeff. & t Value \\
\hline Intercept & -0.4042 & $-7.45^{* * *}$ \\
\hline Targetcandidate & -0.0155 & $-2.18^{* *}$ \\
\hline Size target & 0.0125 & $6.25^{* * *}$ \\
\hline Leverage_target & -0.0631 & $-6.67^{* * *}$ \\
\hline Growth_target & 0.0202 & $3.43^{* * *}$ \\
\hline CFO target & 0.0295 & 1.26 \\
\hline F-value & \multicolumn{2}{|c|}{$5.55^{* * *}$} \\
\hline $\mathrm{N}$ & \multicolumn{2}{|c|}{1264} \\
\hline $\operatorname{Adj}-R^{2}(\%)$ & \multicolumn{2}{|c|}{$8.60 \%$} \\
\hline
\end{tabular}


Table 3 reveals the results of the logistic regression analysis based on the estimation in Equation (4) related to hypothesis 2 , which examines the relationship between financial reporting quality of the target firm and the likelihood of deal completion. As predicted in $\mathrm{H} 2$, the coefficients of AQtarget are positive and significant at the 1\% level. This result indicates that financial reporting quality plays an important role in deal completion. In other words, low financial reporting quality of target firms is positively related to the likelihood of deal withdrawn because the review of financial statements is considered the most important part of due diligence. Based on the first and second results, we argue that when target firms manage earnings excessively, which affects accounting quality negatively, in order to increase transaction value in M\&A, deal withdrawal is more likely to occur.

Table 3. Financial reporting quality of target firms and deal completion

\begin{tabular}{|c|c|c|}
\hline \multicolumn{3}{|c|}{ 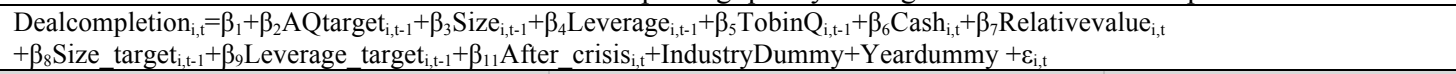 } \\
\hline Variable & Coeff. & $\begin{array}{c}\text { Wald } \\
\text { Chi-Square }\end{array}$ \\
\hline Intercept & -4.6120 & 2.36 \\
\hline AQtarget & 3.3606 & $8.46^{* * *}$ \\
\hline Size & 0.3218 & $6.18^{* *}$ \\
\hline Leverage & -0.3645 & $14.84^{* * *}$ \\
\hline TobinQ & 0.0460 & 0.04 \\
\hline Cash & -0.1081 & 0.07 \\
\hline $\mathrm{Rv}$ & 1.1063 & 1.28 \\
\hline Size_target & -0.0654 & 0.21 \\
\hline Leverage_target & 0.3236 & 0.25 \\
\hline After_crisis & -0.1156 & 0.12 \\
\hline $\mathrm{N}$ & \multicolumn{2}{|c|}{316} \\
\hline Pseudo $\mathrm{R}^{2}(\%)$ & \multicolumn{2}{|c|}{$10.78 \%$} \\
\hline
\end{tabular}

\section{CONCLUSION}

The results of this study demonstrate that management of financial reporting quality in target firms before M\&A, which increases transaction value. In addition, when target firms have a tendency to manage earnings, financial reporting quality is affected negatively, which in turn is associated with deal withdrawal and failure of target firms to be acquired. As such, firms desiring to be targeted should maintain at least a market average level of accounting quality.

\section{ACKNOWLEDGEMENTS}

This work was supported (in part) by the Yonsei University Research Fund (Post Doc. Researcher Supporting Program) of 2015 (Project No.: 2015-12-0001).

\section{AUTHOR BIOGRAPHIES}

Joo-hyun Lim, Ph.D., Professor of Baewha Women’s University, South Korea. E-mail: jhlim@baewha.ac.kr (corresponding author)

Jin-ho Chang, Ph.D., Professor of Yonsei University, South Korea. E-mail: chang@yonsei.ac.kr

\section{REFERENCES}

Bates, T. \& Lemmon, M. (2003). Breaking up is hard to do? An analysis of merger fee provisions and merger outcomes. Journal of Financial Economics 69, 469-504.

Ben-Amar, W. \& Missonier-Piera, F. (2008). Earnings management by friendly takeover targets. International Journal of Managerial Finance 4(4), 232-243.

Botsari, A. \& Meeks, G. (2008) Do acquirers manage earnings prior to a share for share bid?. Journal of Business Finance and 
Accounting, 35 (5\&6): 633-670.

Dechow, P. M., and Dichev, I.D. (2002). The quality of accruals and earnings: the role of accrual estimation errors. The Accounting Review 77(Supplement), 35-59.

Dechow, P., Ge, W., \& Schrand, C. (2010). Understanding earnings quality: A review of the proxies, their determinants and their consequences. Journal of Accounting and Economics, 50, 344-401.

Denis, J.D. \& Macias, A.J. (2011). Material adverse change clauses and acquisition dynamics. Working Paper. Purdue University and Texas Christian University.

Erickson, M. \& Wang, S. (1999). Earnings management by acquiring firms in stock for stock merger. Journal of Accounting and Economics, 27(2),149-176.

Easterwood, C.M. (1998). Takeovers and incentives for earnings management: an empirical analysis. Journal of Applied Business Research 14(1), 29-47.

Fields, T., Lys, T. \& Vincent, L. (2001). Empirical research on accounting choice. Journal of Accounting \& Economics, 31, 255307.

Guan, L., Wright, C.J. \& Sun, L. (2004). Earnings management in targeted hostile takeover firms. Journal of Forensic Accounting, 5(2), 421-432.

Louis, H. (2004). Earnings management and the market performance of acquiring firms. Journal of Financial Economics, 74,124-148.

Marquardt, C.A., \& Zur, E. (2012). The Role of Accruals Quality in the M\&A Market. Working paper, Baruch College.

McNichols, M. \& Stubben, S. (2012). The effect of target-firm accounting quality on valuation in acquisitions. Working paper. Stanford University.

North, D.S. \& O'Connel, B.T. (2002). Earnings management and mode of payment in takeovers. Working Paper. University of Richmond.VA. 34.

Teoh, S.H., Ivo, W. \& Wong, T. (1998a). Earnings management and the long-run underperformance of seasoned equity offerings. Journal of Financial Economics (50), 63-100

Teoh, S.H., Welch, I., \& Wong, T.J. (1998b). Earnings management and the long-run underperformance of initial public equity offerings. Journal of Finance, 53, 1935-1974.

Yoo, Y.T., Lim, J.H., \& Chang, J.H. (2013). Financial reporting quality and acquisition profitability: evidence from korea. The Journal of Applied Business Research, 29(6), 1737-1750. 
APPENDIX I. Variable definition

\begin{tabular}{l|l}
\hline \multicolumn{1}{c}{ Variable } & \multicolumn{1}{c}{ Definition } \\
\hline AQtarget & financial reporting quality of target firm as measured by Dechow and Dichev (2002) \\
\hline Size & natural logarithm of total asset of acquirer \\
\hline Leverage & the book value of debt scaled by the total book value of assets of acquirer \\
\hline TobinQ & the ratio of an acquirer's market value of assets over its book value of assets \\
\hline Cash & 1 if acquisitions are financed fully by cash, and 0 otherwise \\
\hline Relativevalue & deal value divided by acquirer's market value \\
\hline After_crisis & 1 if the acquisition occurred after the financial crisis of 2008. \\
\hline Targetcandidate & 1 if a firm is target candidate, and 0 otherwise. \\
\hline Size_target & target's size, the natural logarithm of total asset \\
\hline Leverage_target & target's leverage, the book value of debt scaled by the total assets \\
\hline Growth_target & target's growth rate, changes in sales divided by total asset. \\
\hline CFO_target & target's operating cash flow divided by total asset. \\
\hline Dealcompletion & 1 if the deal is completed, and 0 otherwise. \\
\hline
\end{tabular}

